International Journal of Multidisciplinary Research AND ANALysis

ISSN(print): 2643-9840, ISSN(online): 2643-9875

Volume 04 Issue 09 September 2021

DOI: 10.47191/ijmra/v4-i9-03, Impact Factor: 6.072

Page No.- $1210-1213$

\title{
Problems with the Procedure for Granting Annual Leave and Suggestions for Their Solution
}

\section{Guljakhon Ruzimboy qizi Madrakhimova}

Independent Researcher, University of Public Safety

ABSTRACT: The article examines and analyzes the procedure for granting annual leave to employees, problematic aspects of the application of legislation in this area, and also proposes proposals for their elimination based on the experience of foreign countries.

KEYWORDS: Employee, Leave, Right To Annual Leave, Vacation Schedule, Work Year, Calendar Year, International Standards.

\section{INTRODUCTION}

The right to rest and vacation, which is recognized as an integral part of human rights, is an integral part of the legal status of every employee and manifests itself as a guarantee provided by the state. Providing employees with annual leave is aimed at compensating for the physical and mental stress received in the process of work, as well as restoring new strength and resources to continue working and maintaining proper health.

The universal international instrument adopted by the United Nations enshrines Article 24 of the Universal Declaration of Human Rights that "Everyone has the right to rest and leisure, including the right to limit his working day and to leave." [1. 118]

Article 38 of the Constitution of the Republic of Uzbekistan strengthens the right of all employees to rest. As noted by President Sh. Mirziyoyev, our encyclopedia fully guarantees the personal rights and freedoms, political, economic and social rights of citizens in full compliance with the requirements of the Universal Declaration of Human Rights and other major international instruments.[2. 103]

\section{THE MAIN FINDINGS AND RESULTS}

The right of employees to rest, in particular, leave, is enshrined in our national legislation. However, it is worth noting that today there are some theoretical and practical problems with the leave, its components, the use of leave, the procedure for granting annual leave. Also, we can not say that the existing international standards on the procedure for granting annual leave and foreign practice fully comply with the rules established by our national legislation.

The duration of the annual leave is not less than the period established by law, and represents a certain amount of time provided to employees for uninterrupted rest and restoration of working capacity while maintaining average wages and employment [3. 219].

According to Article 133 of the Labor Code of the Republic of Uzbekistan, all employees, including those working on a part-time basis, are granted annual leave with a place of work (position) and salary for rest and rehabilitation. All employees, regardless of the form of ownership and the permanent, fixed, seasonal nature of the employment relationship, have the right to receive paid annual leave.

Every employee who has concluded an employment contract and has established an employment relationship with the employer is entitled to annual leave established by law. The right of employees to annual leave does not depend on the place of work, the job performed, the form of ownership based on the economic activity carried out in the enterprise, the term of the employment contract, working hours, etc.

Part-time workers with the right to annual leave are workers who work both part-time and part-time, home workers, individuals working under individual labor contracts, employees sent to enterprises by local labor authorities at the expense of 


\section{Problems with the Procedure for Granting Annual Leave and Suggestions for Their Solution}

the minimum number of jobs, other persons working at the base, as well as persons sentenced to correctional labor on a general basis.

Article 139 of the Labor Code establishes the general rule for calculating the period of leave of an employee on the calendar. In accordance with this article, the duration of leave is calculated in calendar working days on a six-day working week. Holidays that are not considered working days coincide with the holiday period, these holidays are not taken into account in the calculation of the holiday period. This arrangement ensures that the holidays have the same duration in both the five-day and six-day work weeks. When calculating the total period of annual leave, additional leave is added to the annual main leave, including extended leave.

When summarizing the leave established by the legislation, their total duration should not exceed 48 working days. When calculating the duration of holidays in proportion to the time worked, their duration is determined for each full year of vacation. In this case, days equal to or more than 15 calendar days are considered as one month, and less than 15 calendar days are excluded.

According to Article 134 of the Labor Code, the period of annual basic leave is set at least 15 working days. Certain categories of employees are entitled to extended annual leave, taking into account their age and health, in particular, to persons under 18 years of age - 30 calendar days; Persons with disabilities of groups I and II - 30 calendar days of leave.

The legislation also provides for annual extended leave for certain categories of employees, taking into account the specifics and characteristics of their job responsibilities, as well as other circumstances. It should also be noted that the total and minimum duration of extended leave is set. Therefore, in addition to those specified in labor laws or other regulations, the terms of the employment contract may also provide for extended annual leave.

As a rule, annual basic leave is granted after six months of service for the first working year. The working year is calculated from the date of appointment under the employment contract.

Annual basic leave is granted at any time of the working year in accordance with the leave schedule for two and subsequent working years. The order of granting annual leave shall be determined in accordance with the schedule before the beginning of the calendar year. The schedule will be completed after the end of the semester, taking into account the number of newly hired employees during this period. The vacation schedule is approved by the employer in conjunction with the trade union committee or other representative body of the employees.

The legislation also allows for the division of the holiday into parts. At the request of the employee, it is permissible to divide the leave into parts on the basis of his written application. In this case, the part of the vacation used should not be less than 12 working days.

With the adoption of the Labor Code of the Republic of Uzbekistan, the legislation on holidays has entered a new stage of development. It can be said that this document reflects the current trends in the development of state and law, as well as the norms governing the types and conditions of leave, the conditions and procedure for granting leave, which meet the requirements of international standards. Since then, the process of harmonization of previously existing documents with the Labor Code has begun, as well as the adoption of new rules for the implementation of this code. However, today there is a need to develop norms that determine the conditions and procedure for granting leave on the basis of international standards and the experience of foreign legislation. The implementation of international labor standards in our country and the inclusion of new terms in the labor legislation, based on world experience, show the need for the adoption of a new version of the Labor Code in our country. The new version of the draft Labor Code of the Republic of Uzbekistan, developed by the competent authorities and submitted for public discussion, includes a separate paragraph entitled "Annual leave" (§ 4), which contains Articles 228-247. A comparative analysis of the norms governing the annual leave included in the draft of this document with the existing norms in the current Labor Code and the existing problems in practice, as a result of studying the experience of foreign countries, the following recommendations are made:

Article 16 of the Labor Code of the Republic of Uzbekistan (Employee's basic labor rights) states that leave provided by paid annual leave is the right of every employee. However, in practice, there are many examples of complete and partial waiver of the right to leave, denial or restriction of this right by the employer. Therefore, it is expedient to include the norms prohibiting the right to leave and restriction of this right in the chapter or paragraph "Labor leave". The strengthening of this right in this order is the experience of a number of foreign countries. In particular, the right to paid annual leave is enshrined in Article 149 of the Labor Code of Belarus (Right to Labor and Social Leave)[4], Article 31 of the Labor Code of Georgia (Period of Vacation) [5], Article 149 of the Latvian Labor Code (Paid Annual Leave)[6], Moldovan Labor Article 112 of the Labor Code (Annual paid leave) [7], Article 91 of the Labor Code of Tajikistan (the right to paid annual leave and social leave) [8]. For example, the Latvian Labor Code (Article 149) provides for the right of each employee to annual paid leave, and the Labor Code of Tajikistan (Article 91) provides for the right to annual paid leave if there are grounds provided for in this Code. 
"Right to leave" and "right to leave" are different. In particular, the conclusion of an employment contract by an employee with the employer creates his right to leave, and the length of the employee's working period creates his right to leave. The fact that the Labor Code of Moldova (Article 112) cannot be the subject of waiver, denial and restriction of the right to leave, the Labor Code of Georgia (Article 31) provides for the waiver or denial of the right to annual paid leave the terms of the employment contract are not valid. Based on this experience and in order to ensure the use of employees' leave, it is proposed to supplement the Labor Code with an appropriate provision: "The right to paid annual leave cannot be waived, denied or restricted. Any agreement to deny this right in whole or in part is not valid".

An individual approach is required by the employer in calculating each employee's leave. Regardless of the time of the year in which each employee is hired, the norm stipulating that the working year, which is considered to be granted annual leave, is a period of work equal to the calendar year, must be strengthened by current legislation. Therefore, it is expedient to clarify the term "working year" in the Labor Code. Based on the study of Article 163 (Working Year) [9] of the Labor Code of Belarus and Article 124 (Working Year)[10] of the Labor Code of the Kyrgyz Republic, it is proposed to supplement the draft Labor Code of the Republic of Uzbekistan with the following provisions:

"An annual leave is a period of work equal to one calendar year and is calculated for each employee from the time of employment".

The coronavirus pandemic, now known as COVID-19, which has complicated the economic, social and other sectors of the peoples of the world, has in practice created a number of problems in labor relations between employers and employees. "The coronavirus is not only a global health crisis, but also a serious crisis in the labor market and the economy," said Gay Ryder, director-general of the International Labor Organization. [11] Problems with the regulation of working hours, working hours, vacations and remuneration of employees in connection with the declaration of quarantine or state of emergency in many countries around the world have shown shortcomings in the existing regulations. In this situation, there was a need to create a legal basis for the procedure for granting an employee annual leave by the employer, as an exception, without complying with the leave schedule. Therefore, it is proposed to include in the Labor Code of the new draft the following provision, which provides for the granting of leave by the employer in exceptional cases without complying with the leave schedule:

"The employer has the right to grant annual leave to all or certain categories of employees in the event of unforeseen circumstances and in the event of sudden suspension of work due to lack of raw materials, energy supply, natural disasters, losses".

Today, due to the increase in the volume of work in practice, there is a recall of employees from early leave. Special attention should be paid to the protection of the rights and interests of the employee recalled from leave in the legislation. That is, failure to comply with the employer's request to recall the leave should not be considered a violation of labor discipline, and the unused portion of the leave should be given to the employee at another time during the year or added to the next year's leave.

Based on the study of international labor standards and the rules set out in the Russian Labor Code (Article 125) and the Labor Code of Kazakhstan (Article 95), it is proposed to introduce the following rules for recalling an employee from annual leave:

"Withdrawal from leave is allowed only in cases where it is necessary to continue work in an unpredictable situation, which requires the written consent of the employee. The grounds, conditions and procedure for recall from leave shall be determined by a collective agreement and other local documents.

Failure to comply with the employer's request for recall from leave shall not be considered a violation of labor discipline.

Payment for unused leave due to recall is not refundable by the employee. An employee recalled from leave shall be paid on a general basis.

The unused part of the leave must be given to the employee at another time during the current working year or added to the leave for the next working year. Refusal to use the remainder of the leave by the employee is not valid".

Conclusion

Currently, it is important to harmonize and improve the regulatory framework for the provision of annual leave to employees in accordance with international labor standards. In our opinion, in order to eliminate the existing problems in the practice of granting annual leave to employees, to protect their rights and interests, it is advisable to take into account the above suggestions in the next reading of the new draft Labor Code. 


\section{Problems with the Procedure for Granting Annual Leave and Suggestions for Their Solution}

\section{REFERENCES}

1) Human rights. Curriculum for higher education institutions. Responsible muh.H.B.Boboev, I.R.Ramazonov. - T: Uzbekistan, 1997. -P.188.

2) We will resolutely continue our path of national development and raise it to a new level. Sh.Mirziyoev.-T: Uzbekistan, 2017. -P.103.

3) Hasanov M.Yu., Sokolov E.A. Working time and rest time. Tashkent: Ukituvchi, 2000. -P.219.

4) https://belzakon.net

5) https://matsne.gov.ge

6) https://e-seimas.Irs.It

7) https://e-seimas.Irs.It

8) https://mehnat.tj

9) https://belzakon.net

10) https://cbd.minjust.gov.kg

11) G.Madrakhimova. "Problems in the application of the legislation on holidays in Uzbekistan and proposals for their elimination" (Based on a comparative analysis with the legislation of foreign countries). Journal of Critical Reviews (ISSN-2394-5125-Vol 7, Issue 6, 2020).- Б. 403-407. 